\title{
Phosphorus and organic matter in wetland sediments: analysis through gel permeation chromatography (GPC)
}

\author{
Rodolphe GILbIN, Elena Gomez, Bernadette PICOT* \\ Département Sciences de l'Environnement et Santé Publique, UMR CNRS 5556, \\ Faculté de Pharmacie, 15 av. Ch. Flahault, 34060 Montpellier Cedex 2, France
}

(Received 20 September 1999; revised 29 February 2000; accepted 16 May 2000)

\begin{abstract}
Sequential extraction defines fractions of phosphorus of distinct natures and properties in sediments. The organic fraction is partially characterised, sometimes regarded as refractory and stable in spite of variations observed in situ. The unidentified fractions are generally judged complex forms associated with the humic substances. The organic forms of phosphorus were extracted by alkaline solution, following extraction of the inorganic and hydrolysable organic forms in an acid solution. In the sediment of an eutrophic coastal lagoon, organic phosphorus extracted with $\mathrm{NaOH}$ accounts for $18 \%$ of total phosphorus and $79 \%$ of the organic fraction. In order to better characterise the organic phosphorus in the sediments, the GPC chromatography technique was used. Thus several distinct organic fractions were observed: condensed humic acids, with a low phosphorus content, and molecules of molecular compactness, such as fulvic acid which contains the majority of the phosphorus.
\end{abstract}

phosphorus / organic matter / sediment / wetland / gel permeation chromatography

Résumé - Interactions du phosphore et de la matière organique dans le sédiment d'une zone humide. Des extractions séquentielles permettent de définir des fractions de phosphore de nature et de propriétés distinctes dans les sédiments. La fraction organique est partiellement caractérisée, parfois considérée comme réfractaire et stable malgré des variations quantitatives observées in situ. Les fractions non identifiées sont généralement assimilées à des formes complexes associées aux substances humiques. Des formes organiques du phosphore ont été extraites par une solution alcaline, après extraction des formes inorganiques et des formes organiques hydrolysables en milieu acide. Dans le sédiment d'une lagune côtière eutrophe, elles représentent $18 \%$ du phosphore total et $79 \%$ de la fraction organique. Dans le but de mieux caractériser la nature du phosphore organique des sédiments, nous avons utilisé la technique de chromatographie de perméation sur gel. Ceci a permis de définir plusieurs fractions organiques distinctes : des acides humiques condensés contenant peu de phosphore et des molécules de plus faible encombrement moléculaire, de type acide fulvique, contenant la majorité du phosphore.

phosphore / matière organique / sédiment / zone humide / chromatographie de perméation sur gel

Communicated by Isabelle Lamy

* Correspondence and reprints

dsesp@crit.univ-montp2.fr 


\section{Introduction}

In order to characterise the status of phosphorus in sediments, sequential extractions have been developed $[23,46]$. These schemes use $\mathrm{NaOH}(0.1 \mathrm{M}$ or $1 \mathrm{M}$ ) for extraction of iron and aluminium-bound phosphorus and $\mathrm{HCl}(0.5 \mathrm{M})$ for extraction of calcium-bound phosphorus. Others [34] use bicarbonate dithionite to extract iron-bound phosphorus under reducing conditions. The organic phosphorus pool is quantified by the difference between total phosphorus and the other inorganic fractions. These methods have been strongly criticised [4, 5]. During $\mathrm{NaOH}$ extraction, a re-precipitation of extracted phosphorus with calcium causes an underestimation of iron-bound and organic phosphate. Organic phosphate is also hydrolysed during acid extraction.

To avoid these disadvantages, an extraction scheme using chelating agents was developed for the extraction of inorganic phosphorus pools with lesser modifications of the organic pool, the "EDTA method" $[14,15]$. Ca-saturated EDTA (avoids Cabound phosphate removal) renders the iron soluble at the same time as the phosphate and the $\mathrm{pH}$ avoids re-precipitation. Then, Na-EDTA renders calcium and bound phosphate soluble, minimising the extraction of organic materials. Developed by De Groot [4], the "EDTA method" authorises the extraction of two fractions of phosphorus called humic and fulvic bound (Humic-P and Fulvic-P). Applied to sediments of two coastal lagoons, these pools represented respectively 20 and $60 \%$ of organic phosphorus [31]. The use of $\mathrm{NaOH}$ and $\mathrm{H}_{2} \mathrm{SO}_{4}$ for obtaining these two fractions corresponds to the classical methods of separation of humic and fulvic acids in soils. For a better characterisation of these extracts, further measurements are needed.

A specific enzymatic analysis using phytases $[4,31]$ allows us to characterise the part of phosphorus extracted with fulvic acids such as phytate (inositol hexaphosphate). Such organic molecules, derived from plants, accumulate in soils [40] and are likely to accumulate in sediments of wetlands, depending on the $\mathrm{pH}$ conditions $[6,45]$, in spite of their algal or bacterial origin [31].
The Gel Permeation Chromatography (GPC) technique on Sephadex gels (Pharmacia Fine Chemicals, Uppsala, Sweden) was largely utilised for biomedical applications [8, 11]. It was also used for the separation of the phosphorus forms in water $[26,28,3032]$. The separated molecules are dissolved humic substances [30]; the phosphorus they contain is expected to be partly bioavailable [38]. GPC also allows the separation and identification of small molecules, such as free esters of inositol [10] or phytate linked to molecules of high molecular weights (fulvic acids, proteins and lipids) [22]. This technique was initially applied to soil extracts derived from solid phases of the soil [1, 2, 41], then on organic extracts of sediments, in order to study the distribution of the humic substances [36]. Studies with GPC showed relations between metals and phosphates and organic matter in coastal sediments [25] or dissolved organic phosphorus from sediments characterised as phytate [27].

GPC seems an advantageous technique in order to study the fractions of organic phosphorus, especially those linked to the humic substances.

Wetlands are defined as areas where water covers the soil, or is present either at or near the surface of the soil all year or for varying periods of time during the year [43]. In France, urban waste water treated for organic matter but not for phosphorus removal reaches some coastal wetlands that become hypereutrophic. Such wetlands seem appropriate for the study of phosphorus linked to organic matter.

The aim of our work was to examine the ability of the GPC technique to describe organic compounds extracted from sediments of a wetland. Molecular weight distribution of organic molecules and phosphorus associated in the extracts have to be measured. This will contribute to a better characterisation of the phosphorus status in wetland sediments.

\section{Materials and methods}

\subsection{The site}

Sediment and algae were sampled in a brackish saltwater lagoon: the "Étang de Méjean", on the 
Mediterranean coast $\left(4^{\circ} \mathrm{E}\right.$ and $43^{\circ} 40^{\circ} \mathrm{N}$, Hérault, France. $7.47 \times 10^{6} \mathrm{~m}^{2}$ ). Water salinity ranges from 9 to $31 \%$ o. It receives pollution mainly from urban waste water of Montpellier (300 000 inhabitants). Surface sediment $(0-5 \mathrm{~cm})$ is very small (the $<63 \mu \mathrm{m}$ fraction represents $79 \%$ ) and is always submerged. Water content (63\% of wet weight) and porosity $(80 \%)$ are fairly constant throughout the year. The low depth of water $(<1 \mathrm{~m})$, isolation from the sea and slow rate of water renewal make this lagoon hypereutrophic [18-20], which appears by a macroalgae proliferation.

The period chosen for sampling Ulva and sediment (spring) corresponds to the beginning of macroalgae growth (Ulva rigida C. Agardh and Gracillaria verrucosa (Huds.) Papenfuss are the dominant species in this lagoon), where surface sediment is still oxic. Undisturbed sediments, under a $0.7 \mathrm{~m}$ water column, were sampled with a manual corer [35]. The 0-5 cm layer was sampled. Sediment temperature was $13.5^{\circ} \mathrm{C}$ and the $\mathrm{pH}$ 7.7. The $\mathrm{E}_{\mathrm{H}}$ profile showed oxidising conditions in the 0-5 cm layer (190 to $0 \mathrm{mV}$ ) and reducing conditions between 5 and $20 \mathrm{~cm}(-80 \mathrm{mV})$. Initial sediment characteristics for in vitro experiments were determined after sieving to $2 \mathrm{~mm}$. Ulva thalli were sampled, sieved, and rinsed with tap water in order to eliminate salt before determination of dry matter. Water used for the in vitro experiment was nutrientpoor seawater (filtered on Whatman GF/C).

\subsection{In vitro experiment}

Phosphorus fractionation and GPC were carried out on the sampled sediment in its initial form and after in vitro Ulva addition. The aim of this macroalgae addition was to increase the organic content of the sediment, as it occurs in the lagoon when macroalgae reach the sediment. The mixture was incubated in salt oxic conditions for 69 days: $500 \mathrm{~g}$ of fresh sediment $(63 \pm 5 \%$ d.w. water content; $3.23 \pm 0.07 \mathrm{mgN} \cdot \mathrm{g}^{-1}$ d.w.; $45 \pm 5 \mathrm{mgC} \cdot \mathrm{g}^{-1}$ d.w. Corg; $\mathrm{C} / \mathrm{N}=12 \pm 2$ ) and $500 \mathrm{~g}$ of fresh Ulva thalli $\left(87 \pm 5 \%\right.$ d.w.water content; $44 \pm 1 \mathrm{mgN} \cdot \mathrm{g}^{-1}$ d.w. $)$ were incubated with $4 \mathrm{~L}$ of seawater $\left(20^{\circ} \mathrm{C}\right.$, in the dark) in a $25 \times 50 \mathrm{~cm}$ glass aquarium equipped with an oxygenation system (compressed air injected), in order to maintain oxidising conditions. Sediment was analysed for phosphorus and GPC was used to study organic extracts after 69 days of incubation.

\subsection{Analytical methods}

Soluble reactive phosphate (SRP) was analysed according to the APHA "Ascorbic acid" Standard Method (1992) [3]: Ammonium molybdate and potassium antimonyl tartrate react in an acidic medium with orthophosphate to form a heteropoly acid -phosphomolybdic acid- that is reduced to intensely coloured molybdenum blue by ascorbic acid. Total phosphorus was analysed as SRP after persulphate digestion, according to the APHA Standard Method (1992) [3].

Phosphorus in sediment, algae and in the in vitro mixture was fractionated following the sequential extraction scheme (Fig. 1) according to De Groot and Golterman (1993) [6]. First, the sample was washed with $\mathrm{H}_{2} \mathrm{O}$ and analysed as SRP $\left(\mathrm{H}_{2} \mathrm{O}-\mathrm{P}\right.$ fraction). Then, inorganic forms of phosphorus in the sediment (Inorganic-P) were extracted: ironbound phosphate was extracted with buffered CaEDTA/dithionite (CaEDTA-P) and calciumbound phosphate with $\mathrm{Na}_{2}$ EDTA $\left(\mathrm{Na}_{2}\right.$ EDTA-P) [14], both analysed as SRP. Then a dilute acid solution $\left(\mathrm{H}_{2} \mathrm{SO}_{4} 0.25 \mathrm{M}\right)$ was used to extract acid-soluble organic phosphorus (Organic- $\mathrm{P}_{\mathrm{ac}}$ ), analysed as SRP. The molecules extracted are considered as having biochemical components such as nucleic acids, lipids and sugars $[4,17,31]$.

The remaining Organic-P (Organic- $\mathrm{P}_{\text {alk }}$ ) was extracted with $2 \mathrm{M} \mathrm{NaOH}, 90{ }^{\circ} \mathrm{C}$ for 30 minutes. Humic acids were precipitated from the $\mathrm{NaOH}$ extract by acidification to $\mathrm{pH}=1$ with $\mathrm{HCl}$ and collected by filtration (Whatman GF/F). Humic-P is defined as the part of Organic- $\mathrm{P}_{\mathrm{alk}}$ that precipitates at $\mathrm{pH}=1$ as humic acids, analysed as total phosphate after persulphate digestion. Fulvic-P, remaining in solution, was analysed as total phosphorus. In the same extract, SRP was analysed, and phytate was determined by enzymatic hydrolysis with phytase (Sigma - Crude, from Aspergillus ficuum) [4]. 


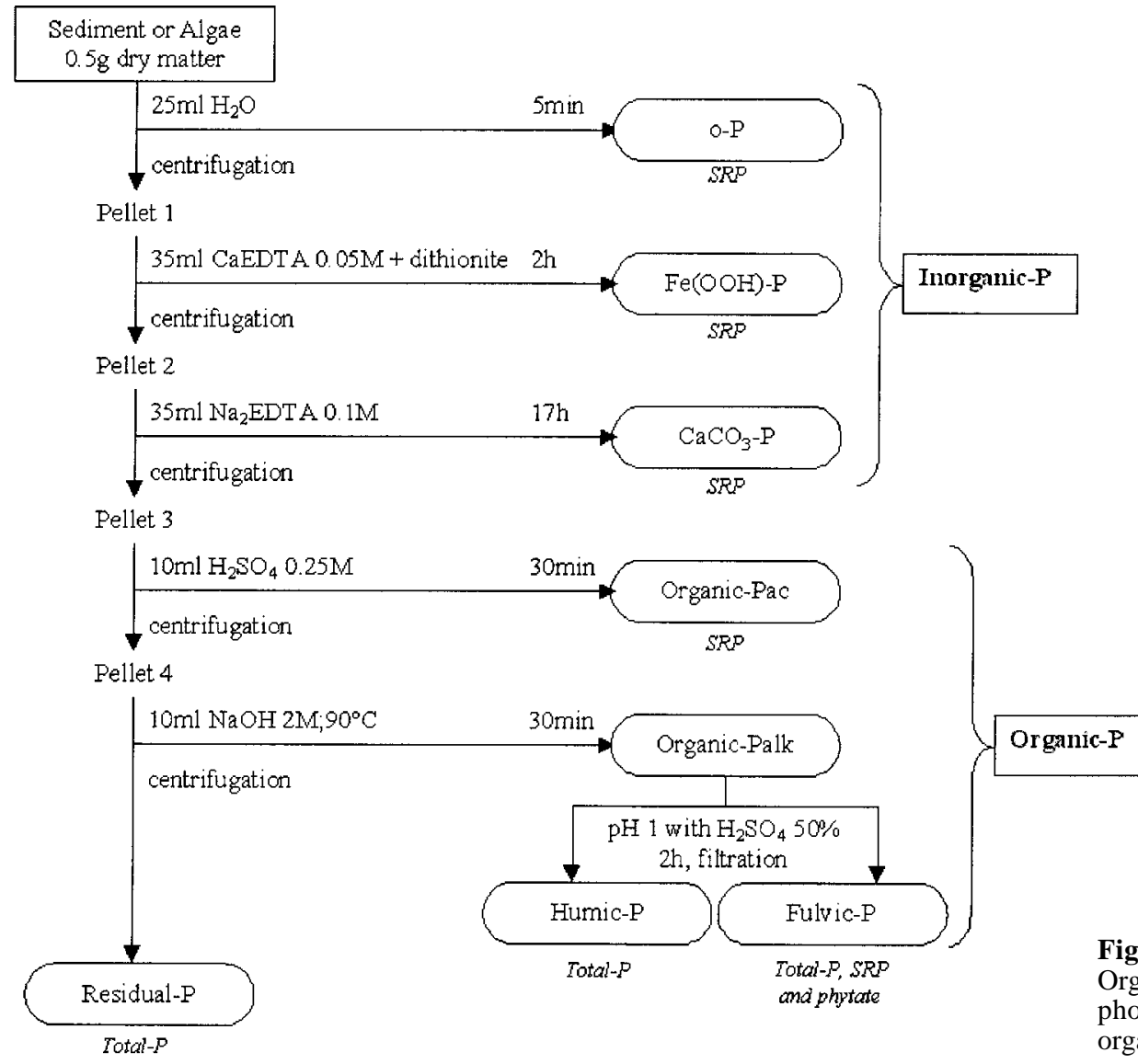

Figure 1. Fractionation scheme. Organic- $\mathrm{P}_{\mathrm{c}}$ : acid-soluble organic phosphorus, Organic- $\mathrm{P}_{\mathrm{alk}}$ : alkali-soluble organic phosphorus.
$\mathrm{pH}$ and temperature (WTW $\mathrm{pH}$ meter), and redox potential (Ingold Pt 4800-M5 electrode corrected for the standard- $\mathrm{H}_{2}$ electrode) were measured in situ in water and in the sediment core. Kjeldahl nitrogen was determined for both sediment and algae according to the APHA Standard Methods (1992) [3]. Weights of dry matter of the sediments and algae were provided at $110{ }^{\circ} \mathrm{C}$ for $24 \mathrm{~h}$.

All reagents were of analytical grade. All glassware was acid washed by immersion in a $10 \% \mathrm{HCl}$ ( $24 \mathrm{~h}$ ) bath and then rinsed with distilled water. All analysis and fractionation schemes were performed in triplicate, and results are given as means with their $95 \%$ confidence interval $( \pm 1.96 \sigma / \sqrt{ } 3)$.

\subsection{Gel Permeation Chromatography (GPC)}

Organic- $\mathrm{P}_{\mathrm{ac}}$, Organic- $\mathrm{P}_{\text {alk }}$, Humic-P (dissolved in $\mathrm{NaOH} 2 \mathrm{M}, 20{ }^{\circ} \mathrm{C}$ ) and Fulvic-P extracts obtained by sequential processes were analysed by GPC on two types of suitably prepared Sephadex gels (Pharmacia Fine Chemicals, Uppsala, Sweden) [8, $11,13]$. G75 medium was used for the separation of molecules < $50000 \mathrm{Da}$, and G25 for molecules $<5000 \mathrm{Da}$.

Ten to forty $\mathrm{ml}$ of each extract were eluted with $\mathrm{NaCl} 0.5 \mathrm{M}$ in Tris $0.05 \mathrm{M}$ at $\mathrm{pH}=9.5$ in the case of alkaline extracts and with $\mathrm{NaCl} 0.5 \mathrm{M}+\mathrm{HCl}$ at $\mathrm{pH}=2$ in the case of acid extracts. Forty-seven to forty-nine $20 \mathrm{ml}$ elution fractions were collected for the analysis of SRP, phytate, Total-P and compared to phosphorus content in the extracts.

Organic matter was detected by UV $254 \mathrm{~nm}$ absorbance $\left(\mathrm{E}_{254}\right)[12,25,38]$. Absorbance ratios, the E4/E6 ratio (430/665 nm) and the E2/E3 ratio $(254 / 365 \mathrm{~nm})$ [7], were used in order to characterise organic matter: the highest ratios E4/E6 ( 9.6) 
Table I. GPC Columns characteristics. (Ve and Kav means $\pm 95 \%$ confidence interval on three replicates).

\begin{tabular}{|c|c|c|c|c|}
\hline & G25 column & & G75 column & \\
\hline Sephadex Gel Type & $\mathrm{G} 25$ & & G75 & \\
\hline Dimensions $(\mathrm{D} \times \mathrm{h} ; \mathrm{cm})$ & $4 \times 50$ & & $4 \times 50$ & \\
\hline $\mathrm{Vt}(\mathrm{ml})$ calculated & 628 & & 628 & \\
\hline \multirow[t]{2}{*}{ Vo $(\mathrm{ml})$} & $247 \pm 9$ & & $196 \pm 7$ & \\
\hline & $\mathrm{Ve}(\mathrm{ml})$ & Kav & $\mathrm{Ve}(\mathrm{ml})$ & Kav \\
\hline Blue Dextran & $247 \pm 9$ & $0.00 \pm 0.04$ & $196 \pm 7$ & $0.00 \pm 0.04$ \\
\hline Phosphate & $520 \pm 26$ & $0.72 \pm 0.07$ & $700 \pm 35$ & $1.17 \pm 0.08$ \\
\hline Phytate & $320 \pm 16$ & $0.19 \pm 0.04$ & $528 \pm 25$ & $0.77 \pm 0.04$ \\
\hline
\end{tabular}

characterise the smaller molecules; the lowest ratios E2/E3 $(\sim 4)$ characterise fulvic acids with relatively high molecular weights (> $5000 \mathrm{Da})$ and with high phenolic polymer content.

To allow direct comparison of results using different GPC columns, UV absorbance $\left(\mathrm{E}_{254}\right)$ and phosphorus values were plotted against the partition coefficient Kav [37]:

$$
\mathrm{Kav}=\frac{\mathrm{Ve}-\mathrm{Vo}_{\mathrm{o}}}{\mathrm{Vt}-\mathrm{Vo}_{\mathrm{o}}}
$$

where $\mathrm{Ve}=$ elution volume, $\mathrm{Vo}=$ void volume, $\mathrm{Vt}=$ total volume.

Blue Dextran (Pharmacia Fine Chemicals, Uppsala, Sweden), with a nominal molecular weight of $2 \times 10^{6}$ Daltons (excluded from the gel) was used to estimate the void volume of the GPC columns [8].

The characteristics of the two columns used are described in Table I. For each column, the void volume $(\mathrm{Kav}=0)$, the Kav for orthophosphate $\left(\mathrm{KH}_{2} \mathrm{PO}_{4} 1 \mathrm{M}\right)$ and phytate $(1 \mathrm{M})$ were determined. Total volume $(\mathrm{Kav}=1)$ of the GPC columns was calculated. Each chromatogram shows the distribution of phosphorus and UV Absorbance $\left(\mathrm{E}_{254}\right)$.

\section{Results}

The sediment sample was representative of the Méjean lagoon sediments previously described [19, 31]. It contained $723 \mu \mathrm{gP} \cdot \mathrm{g}^{-1}$ (d.w.) of phosphorus with $50 \% \mathrm{Na}_{2}$ EDTA-P, 23\% CaEDTA-P and $18 \%$ Organic-P (Tab. II). The Organic-P fraction was mainly alkali-soluble (21\% Organic- $\mathrm{P}_{\mathrm{ac}} ; 79 \%$ Organic- $\mathrm{P}_{\text {alk }}$ ), and phytate represented $25 \%$ of Organic-P. Ulva contained $3465 \mu \mathrm{gP} \cdot \mathrm{g}^{-1}$ (d.w.), mainly as inorganic forms. Its addition doubled the sediment Total-P (1330 $\mu \mathrm{gP} \cdot \mathrm{g}^{-1}$ d.w.). The inorganic fractions increased by $395 \mu \mathrm{gP} \cdot \mathrm{g}^{-1}$ in CaEDTA-P, $32 \mu \mathrm{gP} \cdot \mathrm{g}^{-1}$ (d.w.) in $\mathrm{Na}_{2}$ EDTA-P and $26 \mu \mathrm{gP} \cdot \mathrm{g}^{-1}$ (d.w.) in $\mathrm{H}_{2} \mathrm{O}-\mathrm{P}$. In the organic fraction, phytate increased by a factor of $2.6\left(85 \mu \mathrm{gP} \cdot \mathrm{g}^{-1}\right.$ d.w. $)$ and Humic-P doubled (43 $\mu \mathrm{gP} \cdot \mathrm{g}^{-1}$ d.w.).

Figure 2 shows the SRP, phytate and organic matter $\left(E_{254}\right)$ chromatograms for the sediment extracts (Organic- $\mathrm{P}_{\mathrm{ac}}$, Organic- $\mathrm{P}_{\text {alk }}$, Humic-P and Fulvic-P). Table III shows total inputs and outputs of phosphorus for each extract (SRP, phytate and Total-P). When comparing SRP in the inputs and in the eluate (sum of the elution fractions), recoveries were good in the Organic- $\mathrm{P}_{\mathrm{ac}}$ extract. For the other extracts there was a lack of sensitivity for Total-P and phytate measurement due to the dilution. Thus, chromatograms gave information more qualitative than quantitative.

In the chromatograms, when SRP was eluted jointly with organic matter, a weak linkage was expected. This linkage was broken by the SRP reagent. The same was true for phytate and organic matter.

Phosphorus in the Organic- $\mathrm{P}_{\mathrm{ac}}$ extract was measured mainly as SRP (> 90\%). GPC (Figs. 2a, 2b) showed two distinct peaks: one of organic matter 

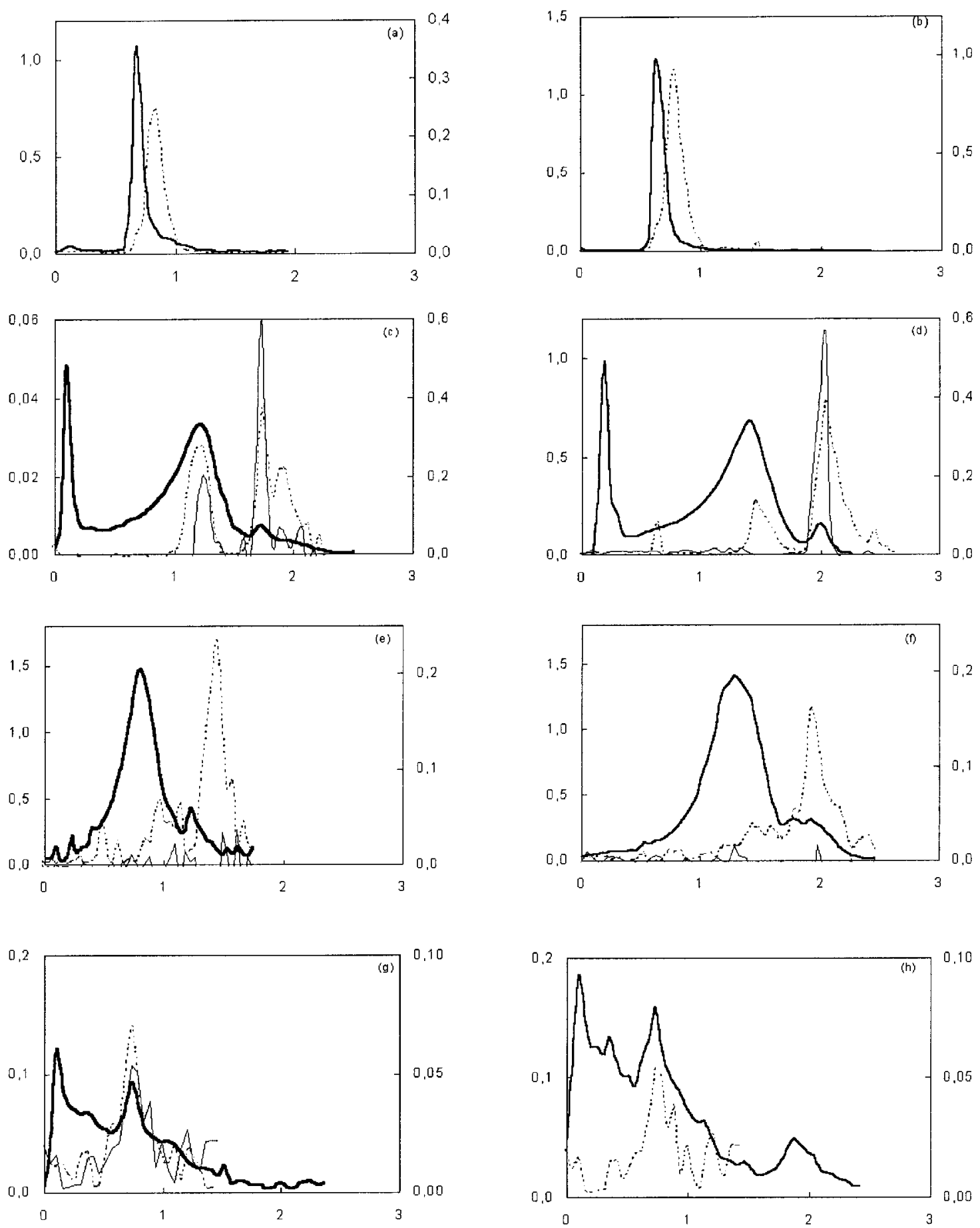

SRP Phytate E254 (AU)

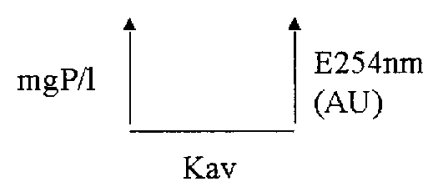


Table II. Characteristics of the Sediment, Ulva, and Sediment + Ulva. In $\mu \mathrm{gP} \cdot \mathrm{g}^{-1}$ of dry matter (Mean $\pm 95 \%$ confidence interval on three replicates).

\begin{tabular}{|c|c|c|c|c|}
\hline & & $\begin{array}{l}\text { Sediment } \\
\left(\mu \mathrm{gP} \cdot \mathrm{g}^{-1} \text { d.w. }\right)\end{array}$ & $\begin{array}{l}\text { Ulva } \\
\left(\mu \mathrm{gP} \cdot \mathrm{g}^{-1} \text { d.w.) }\right.\end{array}$ & $\begin{array}{l}\text { Sediment + Ulva } \\
\left(\mu \mathrm{gP} \cdot \mathrm{g}^{-1} \text { d.w. }\right)\end{array}$ \\
\hline \multicolumn{5}{|l|}{ Inorganic-P } \\
\hline H2O-P & & $6 \pm 2$ & $3356 \pm 49$ & $32 \pm 2$ \\
\hline CaEDTA-P & & $166 \pm 18$ & & $561 \pm 22$ \\
\hline $\mathrm{Na}_{2}$ EDTA-P & & $364 \pm 16$ & & $397 \pm 20$ \\
\hline \multicolumn{5}{|l|}{ Organic-P } \\
\hline Organic- $\mathrm{P}_{\mathrm{a}}$ & & $27 \pm 5$ & $1 \pm 1$ & $23 \pm 1$ \\
\hline \multirow[t]{3}{*}{ Fulvic-P ac } & SRP & $18 \pm 1$ & $5 \pm 3$ & $24 \pm 2$ \\
\hline & Phytate & $47 \pm 15$ & $107 \pm 9$ & $85 \pm 16$ \\
\hline & non id. P & $14 \pm 7$ & $8 \pm 1$ & $116 \pm 10$ \\
\hline Humic-P & & $23 \pm 2$ & $7 \pm 1$ & $43 \pm 2$ \\
\hline Residual-P & & $56 \pm 4$ & $0 \pm 1$ & $49 \pm 2$ \\
\hline Sum Fractions & & $722 \pm 17$ & $3484 \pm 96$ & $1330 \pm 24$ \\
\hline Total-P & & $725 \pm 9$ & $3465 \pm 106$ & $1380 \pm 32$ \\
\hline
\end{tabular}

with a low molecular weight $(\mathrm{Kav}=0.6)$, and one of orthophosphate $(\mathrm{Kav}=0.7)$. Our results (presence of free phosphate probably hydrolysed from extracted organic matter) confirm that this phosphorus pool consisted of small, easily acid-hydrolysed organic molecules.

The Organic- $\mathrm{P}_{\text {alk }}$ extract chromatogram (Figs. 2c, 2d) showed three organic matter peaks $(254 \mathrm{~nm})$. The first peak $(\operatorname{Kav}=0-0.2)$ was humic acids with high molecular weight (> $50000 \mathrm{Da}$; E4/E6 = 2.8). These humic acids did not contain phosphorus. The second peak $(\mathrm{Kav}=1.2-1.4$; E2/E3 $=5-6$; E4/E6 $=8.3$ ) was less condensed humic substances (humic acids of low molecular weight or fulvic acids). The third peak (Kav $=1.7-2)$ consisted in organic molecules of the lowest molecular weights $(\mathrm{E} 2 / \mathrm{E} 3=2.5-3 ; \mathrm{E} 4 / \mathrm{E} 6=4.5) . \mathrm{SRP}$ and phytate were linked to these organic compounds.
In order to confirm the origin of the three observed peaks, humic acids were precipitated by acidification, re-dissolved on $\mathrm{NaOH} 2 \mathrm{M}\left(20{ }^{\circ} \mathrm{C}\right)$ and analysed with GPC (Figs. 2e, 2f). This procedure induced a phosphate transfer from the solution to the humic precipitate. This implies that the method proposed for the quantification of Humic-P overestimates the amount of phosphorus linked to humic acids and underestimates the Fulvic-P pool.

The Fulvic-P extract was injected into the G25 column (Figs. 2g, 2h). A fraction $(\operatorname{Kav}=0$; $\mathrm{E} 2 / \mathrm{E} 3=4.2$, molecular weight $>5000 \mathrm{Da})$ was excluded. It contained a few phosphorus. The organic matter eluted at Kav $=0.7-0.8$ contained SRP and phytate. In spite of the humic precipitation procedure, the phosphorus remained linked to fulvic acids. However, conclusions cannot be drawn concerning the nature of this linkage.

Figure 2. Gel Permeation Chromatograms of organic extracts from the sediments. $\mathrm{X}$-axis: Kav.

Y-axis: $\mathrm{mgP} \cdot \mathrm{L}^{-1}$ (left axis) and Absorbance Unit $\mathrm{E}_{254}$ (right axis) - unequal scales.
(a) Organic- $\mathrm{P}_{\text {ac }}$ extract of sediment
(b) Organic- $\mathrm{P}_{\mathrm{ac}}^{\mathrm{ac}}$ extract of sediment + Ulva
(c) Organic- $\mathrm{P}_{\mathrm{alk}}$ extract of sediment (G25 - Injection $40 \mathrm{ml}$ )
(G25 - Injection $40 \mathrm{ml}$ ) (G75 - Injection $10 \mathrm{ml}$ )

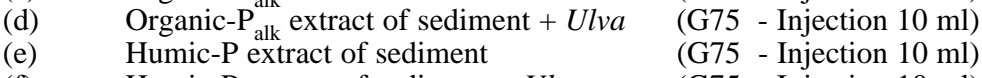
(f) Humic-P extract of sediment $+U l v a$
(g) Fulvic-P extract of Sediment
(G75 - Injection $10 \mathrm{ml}$ )
(G25 - Injection $20 \mathrm{ml}$ )
(h) Fulvic-P extract of Sediment + Ulva
(G25 - Injection $20 \mathrm{ml}$ ) 
Table III. Inputs and outputs of phosphorus (SRP, Phytate and Total-P) in the GPC of the sediment extracts.

\begin{tabular}{cccccccc}
\hline \multirow{2}{*}{ Extract } & Sediment type & SRP & $\begin{array}{c}\text { IN }(\mu \mathrm{gg} \text { P }) \\
\text { phytate }\end{array}$ & Total-P & SRP & $\begin{array}{c}\text { OUT }(\mu \mathrm{g} \text { P) } \\
\text { phytate }\end{array}$ & Total-P \\
\hline Organic-P $_{\text {ac }}$ & Sediment & $54 \pm 9$ & ND & $59 \pm 9$ & 56 & --- & --- \\
& Sediment + Ulva & $54 \pm 2$ & ND & $65 \pm 11$ & 83 & -- & --- \\
Organic-P & Sediment & $17 \pm 1$ & $24 \pm 8$ & $51 \pm 3$ & 7 & 4 & 66 \\
& Sediment + Ulva & $12 \pm 2$ & $43 \pm 8$ & $134 \pm 5$ & 24 & 70 & 115 \\
Humic-P & Sediment & --- & --- & $230 \pm 28$ & 251 & 27 & --- \\
& Sediment + Ulva & --- & --- & $240 \pm 10$ & 229 & 14 & --- \\
Fulvic-P & Sediment & $27 \pm 1$ & $38 \pm 12$ & $82 \pm 7$ & 21 & 21 & --- \\
& Sediment + Ulva & $19 \pm 2$ & $68 \pm 13$ & $225 \pm 9$ & 64 & 48 & --- \\
\hline
\end{tabular}

\section{Discussion}

Extraction schemes allow the separation of several $\mathrm{P}$ pools, but extractants can modify organic compounds, and most of them are not selective. Results obtained with GPC depend on the quality of these extractants. GPC is a useful tool to determine links between phosphorus and organic matter in the extracts: the results showed whether SRP and phytates measured in the different extracts are free or linked with organic matter.

Interactions with the gel of the GPC method have to be examined [27, 37]. Elution times are modified by ionic interactions. As a consequence, results obtained from this work are not useful for the attribution of a molecular weight of organic compounds. Indeed, the partition coefficient Kav was always $>1$ for alkaline extracts. Adsorption of organic compounds on the gel surface was already observed [20], especially with humic substances [24]. Shaw et al. [37] stressed that these molecules, ionised, can undergo a reversible adsorption on the gel matrix. It was shown to be influenced by the $\mathrm{pH}$ and the ionic strength [33, 37]. Moreover, humic substances are modified in their size by a factor of two in terms of ionic strength and $\mathrm{pH}$. We chose a high ionic strength for the elution (0.5) to match the nature of the sediment extracts, but weaker ionic strengths $(0.02$ to 0.05$)$ as well as the use of sodium tetraborate buffers would have been preferable to decrease electrostatic exclusions and adsorption on the gel [21, 42]. Research in progress enabled us to optimise eluent and to improve the chromatography of the extracts, but there was no improvement on the chromatograms. The use of fluorescence, more significant than UV absorbance to identify the organic compounds [7, 29, 39, 44] was also tested. Results obtained confirm those of this study.

Phosphorus associated with humic acids has been considered either as an integral part of humic acids or as a phosphate/metal/organic matter complex [38]. Considering the extraction scheme, complexes with metals should have already been partly extracted from the sediment in the first steps (CaEDTA-P).

Thus, the preliminary results obtained in the present research seem to indicate that organic phosphorus is bonded to organic matter such as fulvic acids rather than humic acids.

In wetlands like the Méjean lagoon, the seasonal cycle of phosphorus was shown to depend on the biological cycle of macroalgae and release from the sediment [18]. The Organic- $\mathrm{P}_{\text {alk }}$ organic fraction increased two times from spring to winter. The turnover of this fraction illustrates the mobility of phytates and fulvic-P.

\section{Conclusion}

The GPC technique, in spite of its limits, allows us to clear up a few questions relative to phosphorus/organic matter relations. In sediments of the studied wetland, phosphorus is associated with 
organic matter of molecular weight that ranged from 500 to $2500 \mathrm{Da}$ (i.e. fulvic acids). The procedure for Humic-P precipitation overestimates the amount of phosphorus linked to humic acids and underestimates the Fulvic-P pool.

It would be interesting to apply it to the extracts of inorganic phosphorus likely to contain organic matter [31] within the same extraction scheme. And even more, a systematic comparison of the various diagrams of phosphorous extraction would be desirable to target more exactly the nature of the compounds in the extracts. Non-destructive techniques used along with the chemical extraction would allow the interpretation of the role of the organic matter in the fate of phosphorus in these aquatic ecosystems.

\section{References}

[1] Anderson G., The isolation of nucleoside diphosphates from alkaline extracts of soil, J. Soil Sci. (1970) 96-104.

[2] Anderson C.A., Black C.A., Separation of organic and inorganic phosphorus in soil extracts by mechanical and chromatographic filtration, Soil Sci. Soc. Am. Proc. 29 (1965) 255-259.

[3] APHA, AWWA, WEF, Standard Methods for the examination of water and wastewater, Greenberg A.E., Clesceri L.S., Eaton A.D. (Eds.), 18th ed., 1992.

[4] De Groot C.J., Some remarks on the presence of organic phosphate in sediments, Hydrobiologia 207 (1990) 303-309.

[5] De Groot C.J., Golterman H.L., Sequential fractionation of sediment phosphate, Hydrobiologia 192 (1990) 143-148.

[6] De Groot C.J., Golterman H.L., On the importance of organic phosphate in some Camargue sediments, evidence for the importance of phytate, Hydrobiologia 252 (1993) 117-126.

[7] De Haan H., Use of ultraviolet spectroscopy and GPC in the study of humification and degradation of aquatic organic matter, in: Christman R.F., Gjessing E.T. (Eds.), Aquatic and terrestrial Humic Material, Sevenoaks, Ann Arbor Science, USA, 1983, pp. 165-182.
[8] Determann H., Chromatographie sur Gel Filtration, Perméation, Tamisage moléculaire, Masson, Paris 1969.

[9] Duchaufour P., Pédologie, 2nd ed., Abrégés Masson, Paris, 1988, 224 p.

[10] Eisenreich S.J., Armstrong D.E., Chromatographic investigation of inositol phosphate esters in lake waters, Environ. Sci. Technol. 11 (1977) 497-501.

[11] Fisher L., Gel filtration chromatographyLaboratory techniques in biochemistry and molecular biology, 2nd ed., Elsevier, Amsterdam, 1980.

[12] Gadel F., Serve L., Garnier E., Vidonne A., Analyse de la matière organique dans les dépôts et les fractions granulométriques, in: Robert M., Verrel J.L. (Eds.), Recherche sur les Sédiments - Rapport Final, Cemagref Antony DGPD/INRA Versailles Ministère de l'Environnement, Paris, 1996.

[13] Galleyrand J.-C., Étude des distributions en masses moléculaires de polymères hydrosolubles par chromatographie sur gel - Etalonnage des colonnes Influence des paramètres expérimentaux, Ph.D. thesis, Montpellier I University, UFR Pharmaceutiques, Montpellier, 1976.

[14] Golterman H.L., Fractionation of sediment phosphate with chelating compounds: A simplification, and comparison with other methods, Hydrobiologia 335 (1996) 87-95.

[15] Golterman H.L., Booman A., Sequential extraction of iron-phosphate and calcium-phosphate from sediments by chelating agents, Verh. Int. Verein. Limnol. 23 (1988) 904-909.

[16] Golterman H.L., Clymo R., Ohnstad M.A.M., Methods for physical and chemical analysis of fresh waters, IBP Manual No. 8, Blackwell Scientific, Oxford, 1978, $213 \mathrm{p}$.

[17] Golterman H., Paing J., Serrano L., Gomez E., Presence of and phosphate release from polyphosphates or phytate phosphate in lake sediments, Hydrobiologia 364 (1998) 99-104.

[18] Gomez E., Fillit M., Ximenès M.C., Picot B., Phosphate mobility at the sediment - water interface of a Mediterranean lagoon (Étang du Méjean). Seasonal phosphate variation, Hydrobiologia 373/374 (1998) 203-216.

[19] Gomez E., Millet B., Picot B., Nutrient accumulation in a lagoon sediment relating to hydrodynamic conditions, Oceanol. Acta 21 (1998) 1-13.

[20] Gomez E., Durillon C., Rofés G., Picot B., Phosphate adsorption and release from sediments of brackish lagoons: $\mathrm{pH}, \mathrm{O} 2$ and loading influence, Water Res. 33 (1999) 2437-2447. 
[21] Hejzlar J., Effect of inorganic salts on adsorption in Sephadex-gel chromatography of aquatic organic substances, Water Res. 21 (1987) 1311-1318.

[22] Herbes S.E., Allen H.E., Mancy K.H., Enzymatic characterisation of soluble organic phosphorus in lake water, Science 187 (1975) 432-434.

[23] Hieltes H.M., Lijklema L., Fractionation of inorganic phosphates in calcareous sediments, J. Environ. Qual. 9 (1980) 405-407.

[24] Hine P.T., Bursill D.B., Gel permeation chromatography of humic acid, problems associated with sephadex gel, Water Res. 18 (1984) 1461-1465.

[25] Hirata S., Phosphorus and metal bound to organic matter in coastal sediments - An investigation of complexes of $\mathrm{P}, \mathrm{Cu}, \mathrm{Zn}, \mathrm{Fe}, \mathrm{Mn}, \mathrm{Ni}, \mathrm{Co}$ and Ti by ICP-AES with Sephadex gel chromatography, Marine Chem. 16 (1985) 23-46.

[26] Lean D.R.S., Movements of phosphorus between its biologically important forms in lake water, J. Fish. Res. Board. Can. 30 (1973) 1525-1536.

[27] McKelvie I.D., Hart B.T., Cardwell T.J., Speciation of dissolved phosphorus in environmental samples by gel filtration and flow-injection analysis, Talanta. 40 (1993) 1981-1993.

[28] Minear R.A., Characterisation of naturally occurring dissolved organophosphorus compounds, Environ. Sci. Technol. 6 (1972) 431-437.

[29] Mittenzwey K.H., Reuter R., Gitelson A., Analyse of dissolved humic substances in eutrophic waters using the fluorescence of natural samples: Calculations and experiences, Int. Rev. Ges. Hydrobiol. 81 (1996) 1-12.

[30] Mullholland P.J., Minear R.A., Elwood J.W., Production of soluble, high molecular weight phosphorus and its subsequent uptake by stream detritus, Verh. Int. Verein. Limnol. 23 (1988) 1190-1197.

[31] Paing J., Gomez E., Picot B., Humic substances interactions with sediment phosphorus, Analusis 27 (1999) 436-438.

[32] Peters R.H., Concentrations and kinetics of phosphorus fractions in water from streams entering lake Memphremagog, J. Fish. Res. Board. Can. 35 (1978) 315-328.

[33] Powell H.K.J., Town R.M., Solubility and fractionation of humic acid, effect of $\mathrm{pH}$ and ionic medium, Anal. Chim. Acta 267 (1992) 47-54.

[34] Psenner R., Puckso R., Phosphorus fractionation: advantages and limits of the method for the study of sedi- ment P origins and interactions, Arch. Hydrobiol. Beih. Ergeb. 30 (1988) 43-59.

[35] Rofés G., Savary M., Description d'un nouveau modèle de carottier pour sédiments fins, Bul. Fr. Piscicult. 283 (1981) 102-113.

[36] Saito Y., Hayano S., Application of high-performance aqueous gel permeation chromatography to humic substances from marine sediments, J. Chromatogr. 177 (1979) 390-392.

[37] Shaw P.J., De Haan H., Jones R.I., Applicability and reliability of gel filtration to study aquatic humic substances revisited; The effects of $\mathrm{pH}$ on molecular size distribution, Environ. Technol. 15 (1994) 753-764.

[38] Stevens R.J., Stewart B.M., Concentration, fractionation and characterisation of soluble organic phosphorus in river water entering LoughNeagh, Water Res. 16 (1982) 1507-1519.

[39] Stewart A.H., Wetzel R.G., Fluorescence/ Absorbance ratios. A molecular tracer of dissolved organic matter, Limnol. Oceanogr. 25 (1980) 559-564.

[40] Suzumura M., Kamatani A., Origin and distribution of inositol hexaphosphate in estuarine and coastal sediments, Limnol. Oceanogr. 40 (1995) 1254-1261.

[41] Swift R.S., Posner A.M., Gel chromatography of humic acid, J. Soil Sci. 22 (1971) 237-249.

[42] Town R.M., Powell H.K.J., Elimination of adsorption effects in gel permeation chromatography of humic substances, Anal. Chim. Acta 256 (1992) 81-86.

[43] USA Government., Wetlands definition, in: USA Government Code of Federal Regulations, Title 40 "Protection of Environment", Chap. I - Environmental Protection Agency, Section 404(b)(1), Guidelines for Specification of Disposal Sites for Dredged or Fill Marerial, Part 230.41, National Archives and Records Administration, USA, 1999.

[44] Visser S.A., Fluorescence phenomena of humic matter of aquatic origin and microbial cultures, in: Christman R.F., Gjessing E.T. (Eds.), Aquatic and terrestrial Humic Material, Sevenoaks, Ann Arbor Science, USA, 1983, pp. 183-202.

[45] Weimer W.C., Armstrong D.E., Naturally Occurring Organic Phosphorus Compounds in Aquatic Plants, Environ. Sci. Technol. 13 (1979) 826-829.

[46] Williams J.D.H., Jaquet J., Thomas R., Forms of phosphorus in the surficial sediment of lake Erie, J. Fish. Res. Board. Can. 33 (1976) 413-429. 